\title{
The Influence of the Absence of Place on the Construction of Intergenerational Collective Memory in a Community of Persons Uprooted from their Homes
}

\author{
Dr. Zeev Greenberg \\ Department of Multi-disciplinary Studies, Tel Hai College, Israel \\ greenbrg@telhai.ac.il \\ Irit Greenberg \\ Research and Education \\ iritgr@walla.ac.il
}

\section{Doi:10.5901/mjss.2013.v4n3p203}

\section{Abstract}

This article examines the construction of collective memory among the residents of the village of Bir'em, who in 1949 were expelled from their homes under temporary military order and, to this day, never allowed to return. Using the theoretical distinction between the terms "space" and "place" (and between different types of spaces), the article describes the transition from the definition of the abandoned village as an undefined space, lacking borders and possessing little meaning to a definition of place possessing physical, personal and social significance. This transition was accomplished through processes of collective memory construction that have enabled the uprooted villagers to transmit that memory to second and third generation descendants. The processes employed were described by participants in thirty-two in-depth interviews and include using the site for transmitting stories at informal family gatherings, communal events and camp programs and for worship at the restored church. The village, itself, is an arena in which two groups compete for the construction of meaning: the Jewish society (through state institutions) that emphasizes its early Jewish history and the uprooted villagers who struggle to preserve structures and stories of the Christian village that was. The social processes of the uprooted community turn the imagined space into a symbolic space of meaning for themselves and for those who were born years after the expulsion.

Keywords: collective memory, Bir'em, symbolic space, imagined space

\section{Introduction}

The village of Bir'em that lay in the Upper Galilee (in the north of Israel) was inhabited by Maronite Christians. In 1949, the Israeli army conquered the village without a fight and three weeks later its inhabitants were asked to leave their village temporarily (Morris, 1987; Ozachy-Lazar, 1993, p. 8; Gelber, 2004, pp. 150-151). Most of the inhabitants went to other villages in the Galilee while others migrated to Haifa and to Jerusalem. Three years later, it was decided to blow up and destroy most of the houses in the village, overturning the prior decision that evacuation of Bir'em was to be a temporary measure for the purpose of securing the new border fence between Israel and Lebanon (Ben Gurion, 1986, p. 354).

This article describes the construction of the collective memory of those who experienced the expulsion directly, and of their second and third generation descendants who also carry memory of uprooting. The site of the village has been undergoing two parallel processes: the first, emptying the village of meaning through the expulsion of its inhabitants and destruction of its houses; the second, constituting the village as a place possessing meaning, this time as an ancient Jewish settlement in the Galilee. The construction of collective memory among the uprooted villagers is being carried out in light of these two processes, and its methods educate us about the meaning of collective memory in the theoretical context of the terms "space" and "place".

Using the terms of collective memory, "space" and "place" as suggested by Padaya (2011, pp. 31-39), the first part of the article describes the village and the unique characteristics of the expulsion of its inhabitants. The article then examines the construction of collective memory of the generations of uprooted villagers through probing the changing meanings of the terms "place" and "space" in their remembrances. The research is qualitative, based upon in-depth interviews with members of the first generation who were children at the time of the expulsion. In-depth interviews were also conducted with their descendants, members of the second and third generations who were raised on stories of the 
place. They possess a collective memory of an event at which they were not even present. The research population was chosen from among community members who participate in conferences and activities organized by the village committee. The research informs us as to what methods of collective memory construction have been employed by various group members and reveals the inter-generational changes of this memory. Moreover, it educates us both about the significance of stories of a place as a means for constructing "symbolic space" and about the methods for creating a feeling of "place" within the "imagined space".

\section{Expulsion of the village residents from their homes}

Bir'em, one of eight Maronite villages of the Upper Galilee, was one of the southernmost villages of the Maronite Christian sect whose center is in Lebanon. The village was located on a hill to the north of Mt. Meron and to the west of the Dishon Stream. As Christians, the village residents were considered a minority in their area. In 1949, the Israel Defense Forces came to the region during Operation Hiram with the goal of taking control of the mountainous Galilee. The army was received without any fighting or resistance (Ozachy-Lazar, 1993, p.8). At that time, the border between Israel and Lebanon was defined in cease-fire agreements that were signed by the two countries earlier the same year (Rosenthal, 1983). Thus, the 1,050 (Archives of the History of the Haganah, 1943; Vaschitz, 1977, p.6) village residents found themselves near the newly established border and cut off from the center of the Maronite sect in Lebanon (Lorech, 1989). The decision to expel the village inhabitants from their homes was made by the commander of the northern front, General Moshe Carmel, in consultation with the military general staff and with the knowledge of the Prime Minister and Minister of Defense David Ben Gurion. The goal of the expulsion, which was defined as temporary, was to create a five to fifteen kilometer wide sterile strip of land on the Israeli side of the new border.

The expulsion of the village residents was problematic for a number of reasons. First, the village residents were Maronite Christians who had good relations with the Jews in the area. Second, according to law, the village residents were citizens of the state of Israel on the day of their expulsion. Third, as stated, the expulsion was defined as temporary in the written expulsion order presented to the village residents, as well as promised to them when they were expelled from their homes (Ben Gurion, 1986, p. 362; Israel High Court Decision 64/51, 3 July 1951, pp. 2-3). After the destruction of the village, the residents were forbidden re-entry in order to prevent their return (Palmon, 1949). To date, some of the uprooted villagers live in the town of Jish, a distance of five kilometers from the abandoned village, while some left the area and others the country. As for the village itself, its buildings were demolished; its homes destroyed, new routes replaced the village pathways and neglect spread over parts of the village. A small number of buildings were turned into service structures for a national park and the church tower remained standing, a protected holy site. In 1972, the villagers began returning to Bir'em to bury their dead in the village cemetery and to hold worship services and religious ceremonies in the restored church. Divesting the village of its meaning over the years and the scattering of its residents are the primary obstacles to constructing a collective social memory.

The state took steps beyond the expulsion and destruction that contributed to emptying Bir'em of its significance as a Maronite Christian village. The goal of these measures was to instill Bir'em with new meaning, unfamiliar and not belonging to the inhabitants that were expelled from it. In 1988, the Israel Antiquities Authority conducted an excavation to re-expose the remains of a Jewish synagogue from the rabbinic period. In the explanatory pamphlet of the national park, it is written that the excavation effort began at the turn of the century and was "renewed" in 1988 by the Antiquities Authority. The synagogue had been situated within the village over the centuries, but after the demolition and destruction of some of the village homes it became more prominent in the middle of the large grass area that is now the center of the national park. The new structure of the park symbolizes and strengthens the connection between the Jewish people and its land and the Jewish religious identity of the space. It does so at the expense of the memory of the village that existed in the place until 1949, reducing the meaning of Bir'em as a Maronite Christian village that was destroyed (Bardenstein, 1999, p. 166).

\section{Collective memory and communal memory}

Construction of collective social memory (Jouhaud, 2009; Gelber, 2007, pp. 231-245) is the product of a societal process that turns past events into a common story possessing meaning for the contemporary society as a whole (Halikowski, 2008). Halikowski (2008) explains that reconstruction of its past by the group assists in its coalescence and in defining its unique attributes, and thus contributes to a feeling of partnership in a shared future. Margalit (1999-2000) claims that constructing a collective memory is the creation of one account that integrates a number of different points of view into 
one story. A collective memory is the property of all and also includes those who were not present at the event but who recognize its importance and are partners to its endowing (Azaryahu, 1996; Hall, 2009). Collective memory and shared stories are loaded onto the space making it symbolic and possessing of meaning for the collective. Moreover, they enable the collective to experience and feel partnership with the story that happened in the place (Azaryahu, 2005; Azaryahu and Foote, 2008; Antonish, 2010). Nora (1984) notes that collective memory is an organic part of the life of every community: it is real, adapts itself to details that are comfortable for it and negotiates between historical testimonies and contemporary events. Herein lays its power and meaning for the society.

Padaya (2011, pp. 36-42) singles out the significance of the historical story precisely where spaces are lacking, in the imagined ones. According to her, passing down the story enables redefining of the space and thus overcoming the "nothingness" or, as she defines it, "the hole" that exists among the community members in the context of the place where they are not but to which they feel they belong. Padaya maintains that the construction of historical story is one of the techniques for verifying and constructing content in spaces that were emptied of their substance and that were turned into imagined spaces.

\section{The difference between space and place and their significance for collective memory}

Padaya distinguishes between the terms "place" and "space": the definition of "place" includes within it the significance and existence of the place, in that it possesses meaning, clear and demarked borders, qualities of time and qualities of historical or religious content that are connected to belief. All of these imbue a place with social significance, making it meaningful for the members of the group. The significance of a place contributes to the construction of a reality among the group members. The definition of "space" is different from that of place in being vaguer: space is an undefined area, lacking borders and hence not given to being marked. It lacks time; therefore it is difficult to pour into it meaning and content. Basing herself upon the model of the registers of human reality of Lacan (2006), Padaya (2011, p. 21) distinguishes between three definitions of space:

Real Space - a concrete space within which exist the material and tangible conditions of life. Real Space is unmarked and borderless and, therefore, is endless; as such, it is inconceivable and difficult to define.

Imagined Space - a space possessing significance that the individual or collective constructs and loads with historical meanings, whose sources are stories of the past, beliefs and social values, all of which imbue the space with the meaning that characterizes it. This space has no defined borders yet is marked by the meanings given to it by the collective.

Symbolic Space - this space can be real or imagined and is characterized by its being made up primarily of symbols and stories that imbue it with meaning. Symbolic space is separate from real space and from imagined space but maintains with them an array of relationships of different natures. This space enables life of significance and intent for members of the collective. The connection that exists between the array of historical, mythic and social symbols in this space and between daily life enables continuous reorganization of the space.

Padaya notes that there exists a two-way process between the definition of place and the definition of space. Place is the 'site of identity' that crystallizes the collective identity through an array of connections that join between the real, the imagined and the symbolic of the collective. Padaya $(2011$, p. 35) also claims that place is different from space in being a defined territorial unit that often lacks the symbolic and mythic burden that characterizes the imagined and the symbolic spaces. The fact that place has defined borders and 'territorial reality' cancels its need for glorification and for the loading of symbols that exists in the transition from real space to imagined or symbolic space.

In the context of the memory of the village, this article examines the phenomenon of the construction of collective memory that enables the uprooted villagers themselves and their descendants to become familiar with the story of the village and to be partners in the collective and to its values. The article will present the different ways in which the uprooted villagers construct collective memory in face of the emptying of the Maronite village of meaning. Furthermore, understanding this process as a reaction to the competing Jewish narrative reveals the constructing of memory as a technique for the marking of and belonging to the space by two groups and against the background of the relationship between a majority and a minority.

\section{Research methods}

This article is based upon thirty-two in-depth interviews (Bruner, 1999; Elon and Tzabar Ben- Yehoshua, 2010) using the phenomenological approach stemming from the qualitative paradigm (Spector-Marzel, 2010). In accord with this 
approach, an attempt was made to represent reality as perceived in the eyes of the research participants. The mapping of their stories, experiences and world of terms enables understanding of the social mechanisms that further construction of the collective memory of the village among the uprooted (Patton, 1990; Weaver, 2009) and among their descendants. The sample of interview participants was created using the "snowball" method, according to which interviewees were asked whether they know others that might agree to be interviewed for the research. The interviews included open questions that examined the characteristics of the memory of the village among the uprooted. The goal of the questions was to examine the meaning of the terms "place", "imagined space" and "real space" and their expressions in the processes of constructing collective memory. In addition, the research examines the imparting of collective memory upon subsequent generations. Analysis of the findings is based up the "Grounded Theory" method, appropriate for use when the research question is general. In this study, as stated above, the assumption is that every generation of uprooted villagers has unique patterns for constructing the memory of the place from which it was expelled.

\section{The significance of landscape in the memory of the uprooted villagers}

In interviews with three generations about their memories of the village, the landscape and different objects stand out in their significance. The landscape, houses and trees bestow memory and deepen the strength of the recollected occurrences in that they combine stories of the place, tastes and experiences that give the place its meaning. One first generation interviewee recalled:

"...I remember the store, it was on the side of the road, and there was also a bus stop there, all the children waited for the bus that arrived from Safed....we would sit for hours next to the store waiting for the bus to return".

Another interviewee said:

"...When I was a girl we would go to pick figs. On our parcel of land we had a small pool where we would bathe in the afternoon. The adults picked figs and we children played in the pool".

Another interviewee from the first generation described the village landscape:

"...Around the village were hills filled with figs. Thick figs...large...meaty... every tree was hundreds of years-old. We knew to whom each tree belonged, to which family..."

Later in the interview he detailed:

"...In the summer, we would sit in the evenings in the entrance to the house and eat figs...they tasted like honey...those cannot be uprooted...they [the trees] are so very old and still bear fruit. Sometimes in the summer children bring me fruit, this is the real taste of figs, this fruit".

Interviewees of the second generation were asked whether in light of the stories they had been told, they feel that they know the village. One of the participants responded:

"...I know all of the houses, I know where the doctor's house was, the priest's house, where the water holes were and where the wells. There was a lot of water in the village, good water; there was fruit here throughout the summer. The figs from the village were known in Safed - they were the sweetest figs in the entire area".

Another interviewee of the second generation said:

"... The village was a very small village, much smaller than Jish ${ }^{1} .$. the village was the prettiest village in the area, you could see the church tower from afar, big trees, in the summer there was a lot of fruit...it was like living in the Garden of Eden".

Another example of idealization of the village before the expulsion was expressed by another interviewee who said:

"...The village was a special place in which to live. It was not like a village of today, it was a real family. There was

\footnotetext{
1 The reference is to the village of Gush Halav, located five kilometers from Bir'em, where some of the expelled villagers live to this day after immigrating there at the time of the uprooting.
} 
familiarity, there was friendship, people felt obligated to one another. In my opinion it is because we are Maronite Christians and are a small ethnic group, in the Galilee and also in Lebanon. But it was a place that was fun to live in. That is a feeling that has not disappeared and still exists today".

Many depictions of the village and its surroundings arose in the interviews. Members of the first and second generation describe the village landscape and life within it even though those of the second generation were not even present during that period. One can assume that the depictions of the landscape and life are part of the collective memory of the entire group. This memory was built with the help of descriptions of the place and stories that the children absorbed during their childhood (Weaver, 2009).

The landscape depictions contain two meanings. One is concrete: landscapes that describe the historical village. The second, more complex, is the symbolic, in that the descriptions of the landscape contain symbols of great meaning for the uprooted. The landscape depictions are allegorical. The description of fig trees are an opposite analogy to the condition of the uprooted, they are described as "strong...large and fleshy"...and later one of the interviewees says: "those cannot be uprooted...they are so very old and still bear fruit". In the stories, the trees are given lofty characteristics filled with mythic meaning in relation to the reality of the life of the uprooted villagers. The description of the trees creates a contrast emphasizing the reality of uprooting against the landscape depictions.

Another example of twofold meaning is seen in the depictions of the church that combine descriptions of the structure with its symbolic meaning. The church tower is prominent in the landscape and is emphasized as possessing significance not only for the village but for the entire area. It symbolizes the religious distinction of the villagers and the village, itself, in opposition to other settlements. In addition, the church tower that is depicted as standing out above its surroundings is a symbolic witness and signpost to what happens in the place. Moreover, similar to the fig trees, the existing tower stands in contrast to the reality of life of the uprooted. As such, it is a symbol with great meaning. If the expulsion and destruction express the emptying of the site of its contents, the turning of a place into a borderless and desolate space whose meaning is unclear, the landscape depictions, among them the church tower and fig trees, come and bestow upon the site its significance. Its meaning is historic, accompanied by memories and symbolism of a utopian state expressing the hopes of the uprooted.

\section{From place to space - methods for constructing collective memory}

From the interviews it is evident that memory of the village has meaning for three generations of uprooted villagers. The memory of the second and third generation was acquired and is based upon stories of family members and upon memory agents operating on behalf of the community (Weaver, 2009). In response to the question about ways of transmitting the village memory to its descendants, one of the interviewees said: "...when you ask my son where he is from, he answers, 'I study in Haifa, reside in Gush Halav and live in Bir'em'". Another interviewee, the mother of three girls, explained techniques for instilling the village memory in her children:

"When my girls get older I will take them to Bir'em and we will start with a picnic. We will start spontaneously. I won't talk to them about mourning. I want them to love the place, to develop on their own a feeling of belonging, and then when they can understand, I will tell them the story so that they will continue the ways of their grandfather".

Another interviewee, a member of the second generation and father of five, described: "...this village is where we spend time, we come here to take walks, to picnic, here we play with our children". Yet another interviewee said:

\footnotetext{
"... Once my child asked me 'father, why do we travel so far to the church to pray?' I explained to him that here is our real home and that this is our real church, and so then I told him about the village, showed him where his grandfather's house was. He is still small, doesn't really understand, when he grows up I will tell him the story of the village and he will know".
}

In addition to preserving the memory in the informal family framework, there is an additional technique employed, that of the village committee. The committee was established in the 1970s as part of the activities of the uprooted villagers to overturn the decision of the government and allow them to return to their village. The committee saw to the restoration of the church and the cemetery. It is also responsible, currently, for ceremonies at the cemetery and church, the web site, publicity, preserving ties and transmitting information to the uprooted villagers and their children. In addition, every summer the committee runs a summer camp for the children of the uprooted villagers on site at the village.

In her interview, the representative of the village committee said: "...we hold social activities that preserve the 
village memory among the young children, who today are the grandchildren of the uprooted villagers and who attend the summer camp every year". Afterwards, she explained how the camp is organized: "...the camp is run by our children, members of the second and third generation... and is filled with summer and fun activities alongside subjects dealing with the story of the village, its leading personalities, the uprooting and the question of return". In his interview, G, a student and camp counselor who has now worked at the camp for two years, said:

\begin{abstract}
"...The encounter at camp is fun, it is a scouting camp with experiences and fun, it is something for the summer, we do activities and games and also mention the village. We meet with elders who tell about what was here, play games among the houses, this is the way they get to know the village and the stories, but the intention is for them to have fun, otherwise they won't come".
\end{abstract}

\title{
$\mathrm{H}^{\prime}$, another counselor in the camp described:
}

\begin{abstract}
"The stories are not about the expulsion, rather about what was here before, who lived here, what it was like when the village existed. We don't want them to remember with sadness rather with happiness. Like my grandfather, may he rest in peace, who described to me the life in the village and my father who told me - now I tell and I know a lot, because the stories are passed down from one to another. Every year that we are here in the summer also helps with the story, we talk about the houses, the people who lived here, how they lived, what they did, what they had, this way the stories of the place are passed on from one to another and this way also the children, in the end, will feel that they belong here".
\end{abstract}

From here we can see how the stories of the village and the activities that happen there turn Bir'em anew into a "place" that has within it a new layer of concrete experiences, both on the family and on the group level. In parallel to the turning of the space to imagined on the part of the establishment - and on the part of the uprooted villagers who preserve the ideal memory of the village that was and is no more - Bir'em receives meaning of place through techniques of story and activities. The former preserves the past and the latter strengthens the significance as "place" in the present. Both contribute to Bir'em's definition as a place of activity, possessing boundaries and significance for the members of the community.

\section{Discussion}

From the descriptions of the interviewees we learn that the village meets the definition of imagined space. This definition comes from its being borderless, undefined and lacking in meaning as a result of the expulsion (Padaya, 2011, p. 35). Moreover, prohibiting the expelled village residents from visiting contributed to the turning of the village into undefined space. Ilan Magat (2000), who wrote the stories of the people of the village, described the village as a "liminal, borderline space. Places like this are located in the in-between. They are not regulated places, not according to law, rite or convention. They are holy and secular at the same time".

Constructing a collective memory among the uprooted villagers gives the space new meaning. The stories of the place and the memories passed down from generation to generation contribute to turning the place into an "imagined space" of deep social and historical meaning. This imagined space is the result of long-term processes of collective memory construction among three generations of uprooted villagers. Here, descriptions of the village landscape play a significant role in two ways. First, examination of the descriptions teaches about the power of the landscape and the objects in the space as symbolizing a utopian and yearned for state, the life that existed before the space became undefined. The landscape descriptions have allegorical meaning, of necessity carrying messages that reveal how the uprooted feel about themselves and their lives. The trees and their fruit are used as a contrasting metaphor: their connection to the place is given expression in the statement "every tree is hundreds of years old" and "they are so old and still bear fruit" - a statement that stands in opposition to the feelings of tearing out and distancing on the part of the uprooted. The contrasting metaphor is repeated through the depictions of the village water. Water is the source of life; the "real taste" of the "good water" is a concrete symbol of the good life of the past. Reflected in it is the borderless, liminal village that is the symbol of the true state of the uprooted.

Second, against processes of emptying the village of meaning, there is a constant process of giving new meaning, turning the real space into imagined space. The use of the village landscapes and the description of the trees and buildings that no longer exist enable the construction of an imagined space possessing the meaning of ancestry for the uprooted villagers and their descendants. Here, the space becomes one with historical, social and even mythic dimensions of significance and bestows new meaning upon the place. 
The dismantling of the village and emptying it of its inhabitants are a political act connected to the relations of power between the majority and the minorities found within its area of control. Two opposing aspects of the state's activities exist in parallel: dismantling and building. Alongside the dismantling of the Maronite village and the turning of it into an undefined space, the site was rebuilt as a place possessing new-old meaning emphasizing its Jewish character and justifying the re-occupation of the space. Construction of historical memory occurs, as such, in parallel for both groups.

Among the uprooted villagers, a number of generations are partners to the processes of memory construction. These processes operate without benefit of the institutionalized mechanisms and practical techniques that exist at the site on behalf of the state. The various activities are part of the struggle between the two groups over the identity of the place. The second and third generations of the expulsion do not remember the village; rather they are familiar with the stories of the memory and with the collective memory that was passed down to them. The encounter between them and the physical space is a pleasant and welcoming encounter based upon enjoyable, personal memories of trips, prayer services at the church and experiential activities. All of these connect them to the place, enabling it to once again be a defined "place" for them, possessing clear borders and the unique characteristics that give it its identity.

From a theoretical aspect one can say that there exist mutual processes of collective memory construction of community and of the space in which it operates. Emptying the place of its meaning and turning it into undefined real space brings about the construction of a collective memory that holds on tightly to stories of the past for the purpose of preserving the memory. Some of the stories of the past describe the place in physical descriptions that weave together objects, landscapes and activities, at times turning mythic in their meaning in the construction of the collective memory. The space is given symbolic meaning and mythic powers that strengthen its significance during construction of the collective memory. This empowerment turns the space into one of meaning. This is the symbolic space that is empowered and decorated with meaningful symbols that define anew its borders, characteristics and roles.

These processes of collective memory construction do not occur from above. They happen informally at the level of the family, the group with the most intimate significance for the individual and with the aid of memory agents who are given the socially significant task of constructing collective memory. Thus, the space in which the activities occur is turned anew into the place. The church, the cemetery, the church courtyard and the summer camp create the reality of place with borders: defined, bounded and possessing rules of behavior in which characteristics of the present reality are connected to the past that no longer exists in one clear and defined point in time that is the new place. This place possesses two layers of reality: the historic and that of the different, renewed present. This place contains within it the shared past and the stories, the symbols and the values that are meaningful within the collective memory. They bring together the collective memory with the reality that is lacking to define a temporary present to which the group members can connect and in which they can participate. To this juncture they bring together all of the components of the collective memory and reality. This is a temporary event that takes place within defined borders, but beyond them it has no existence. Nevertheless, this is an event possessing characteristics of place, because it contains within it components of identity, borders, familiar history, shared memory, rules and practical techniques that are familiar and shared by those who choose it as having significance for them.

\section{Conclusion}

This research examined the characteristics of the construction of collective memory among three generations of the uprooted villagers of Bir'em. The findings shed light on the processes of collective memory construction they employ. From the interviews it became clear that the landscapes and depictions of the village from the days when it existed hold great significance in the memory of all three generations of uprooted villagers. Analysis of the descriptions teaches about the complex meaning of the village landscapes and their integral role in turning the real space into a symbolic space possessing significance. The descriptions also possess allegoric meaning for the lives of the uprooted villagers. Moreover, while the construction of memory takes place among three generations of uprooted villagers, it differs from one generation to the next. The first generation relied on childhood experiences and on stories of memory that they heard from their parents while the memory of the second and third generations is based upon a structured social arrangement that operates defined techniques for constructing collective memory.

From the stories of the memory arises a question regarding the limitations of the research. In order to interview members of different generations, interviewees were recruited using the "snowball" method, according to which every interviewee recommends additional interviewees known to him or her. An additional group may exist among the uprooted villagers that does not participate in the constructing of collective memory and that was not given any expression in this research. The research of memory construction can be expanded to include groups of uprooted villagers that do not 
come to the site, do not participate in rituals and that live far from the village. In addition, it is possible to examine the construction of collective memory of the expelled in its political context, as part of the struggle of the uprooted to preserve their memory and to endow the story of the village in opposition to construction of the collective memory of the site as a Jewish synagogue.

It appears that collective memory is one of the means in the struggle of the uprooted villagers to return to their home. It is a non-violent struggle, planned and long-term, as a result of which the uprooted are permitted to go to the village and to restore and operate the cemetery and the church. This activity enables the uprooted villagers to connect between their collective memory and the activities themselves that take place in the space. In this way, the space is not real and not symbolic; rather it is and has significance in reality. This is a temporary reality, one-time and fragmented, yet, even so, it enables a unique experience of the place for which they are searching and whose memories they carry with them and pass down from generation to generation.

\section{References}

Archives of the History of the Haganah. (1943). File 226 'Safed and its environs', Document Summer 1943. Tel Aviv: Israel Ministry of Defense. (in Hebrew)

Antonisch, M. (2010). Meanings of place and aspects of the self: an interdisciplinary and empirical account. GeoJournal, 75, 119-132.

Azaryahu, M. (2005). Mt. Herzl: Historical layout of the national cemetery in Jerusalem. Ofakim Begeographia, 64-65, 369-383. (in Hebrew)

Azaryahu, M. (1996). Water towers in the landscape of memory. Katedra, 79, 160-173. (in Hebrew)

Azaryahu, M., \& Foote, K. E. (2008). Historical space as narrative medium: on the configuration of spatial narratives of time at historical sites. GeoJournal, 73(3), 179-194.

Bardenstein, C. B. (1999). Trees, forests, and the shaping of Palestinian and Israeli collective memory. In M. Bal, J. Crewe \& L. Spitzer (Eds.), Acts of memory: Cultural recall in the present (pp. 148-168). Hanover and London: University Press of New England.

Ben Gurion, David. (1986). From the diary - War of Independence. G. Rivlin \& E. Oren (Eds). Tel Aviv: Israel Ministry of Defense. (in Hebrew)

Bruner, J. S. (1999). Time, Narrative, and History. Bloomington: University of Indiana Press.

Elon, Y. \& Tzabar Ben-Yehoshua, N. (2010). The process of content analysis according to the grounded theory method. In L. Kacen \& M. Krumer-Nevo (Eds.), Data Analysis in Qualitative Research (pp. 359-382). Beer-Sheva: Ben-Gurion University Press. (in Hebrew)

Gelber, Y. (2007). History, Memory and Propaganda. Tel Aviv: Am Oved Publishers. (in Hebrew)

Gelber, Y. (2004). Uprising and Nakbah. Tel Aviv: Dvir Publishing House. (in Hebrew)

Halikowski Smith, S. (2008). Meanings behind myths: the multiple manifestations of the Tree of the Virgin at Matarea. Mediterranean Historical Review, 23(2), 101-128.

Hall, T. (2009). Footwork: moving and knowing in local space(s). Qualitative Research, 9(5), 571-585.

Israel High Court Decision 64/51, 3 July 1951.

Jouhaud, C. (2009). "Camisards! We were Camisards!": Remembrance and the ruining of remembrance through the production of historical absences. History \& Memory, 21(1), 5-24.

Lacan, J. (2006). On the names of the father: "the symbolic, the imagined and the real". Noam Baruch (Trans.), Tel-Aviv: Resling.

Lorech, N. (1989). The History of the War of Independence. (2nd ed). Tel Aviv: Massada. (in Hebrew)

Magat, I. (2000). Bir'am: a Conscripted Community of Memory. Givat Haviva: The Institute for Peace Studies. (in Hebrew)

Margalit, A. (1999-2000). Continuous past. Zmanim, 68-69, 76-78.

Morris, B. (1987). The Birth of the Palestinian Refugee Problem, 1947-1949. Cambridge: Cambridge University Press.

Nora, P. (1984). Entre mémoire et histoire: La problématique des lieux. In Les lieux de mémoire. In P. Nora (Ed.), Vol. 1,La République, xv-xlii. Paris: Gallimard.

Osachy-Lazar, S. (1993). Iqrit and Bir'em: the full story. Givat Haviva: Institute for Arab Studies /Institute for Peace Studies. (in Hebrew)

Padaya, H. (2011). Expanses: an Essay on the Theological and Political Unconscious. Tel Aviv: Hakibbutz Hameuchad. (in Hebrew)

Palmon Letter to the Mukhtar of Bir'em, 13 June 1949, Israel State Archives, Office of Minorities. (in Hebrew)

Patton, M. Q. (1990). Qualitative Evaluation and Research Methods (2nd ed.). Newbury Park, CA: Sage Publications.

Rosenthal, Y. (Ed.). (1983). Documents of the Foreign Policy of the State of Israel, Vol. 3: Ceasefire talks with Arab countries December 1948- July 1949. Jerusalem: Israel State Archives. (in Hebrew)

Spector-Marzel, G. (2010). Mechanisms of selection in claiming narrative identity. In L. Kacen \& M. Krumer-Nevo (Eds.), Data Analysis in Qualitative Research (pp. 63-96). Beer-Sheva: Ben-Gurion University Press. (in Hebrew)

Vaschitz, Y. (1977). The Bir'em and Iqrit Affair - facts, background, problems, United Workers' Party. Givat Haviva: Department of Publicity and the Center for Arab Studies. (in Hebrew)

Weaver, A. E. (2009) Theological Cartography and the Arboreal Imagination in Israel-Palestine. [Online] Available: http://www.academia.edu/1415176/Theological Cartography and the Arboreal Imagination in Israel-Palestine 